\title{
Weight of selected muscles as an indicator of the lean meat and fat content of broiler carcasses (Short Communication)
}

\author{
KATARZYNA KLECZEK, KAZIMIERZ WAWRO, ELŻBIETA WILKIEWICZ-WAWRO and \\ WŁODZIMIERZ MAKOWSKI
}

Department of Commodity Science and Animal Improvement, University of Warmia and Mazury, Olsztyn, Poland

\section{Abstract}

The objective of this study was to test whether the weight of selected arm and leg muscles and breast muscles may be used as an indicator of the content of lean meat and skin, including subcutaneous and abdominal fat, in the carcasses of broiler chickens. The experimental materials comprised 40 Ross 308 chicks aged 42 days (sex ratio 1:1). A total of 17 muscles were dissected from the right wing and the right leg. The right and left breast muscles were also dissected. Coefficients of simple correlation between the weight of individual muscles and selected slaughter quality parameters were calculated. The highest correlation was found between the lean meat content of a carcass and the weight of the right and left breast muscles ( $r=0.81$ and 0.82 respectively), $m$. gastrocnemius mediale $(r=0.81)$ and $m$. peroneus superficialis $(r=0.73)$. The prediction of the weight of skin and fat in the carcasses of broilers based on the weight of single muscles may be unreliable due to low and non-significant values of correlation coefficients ( $r$ from 0.04 to 0.29 ). The weight of this tissue component was significantly correlated $(r=0.42)$ with breast muscle weight only.

Keywords: broiler chickens, muscles, meatiness, fatness, correlation

\section{Zusammenfassung}

\section{Tauglichkeit einzelner Muskelgewichte zur Bewertung des Fleisch- und Fettgehaltes von Broilerschlachtkörpern (Kurzmitteilung)}

Untersucht wurde die Tauglichkeit der Gewichte von Flügel, Schenkel- und Brustmuskeln für eine Bewertung von Fleisch-, Haut mit Haut- und Bauchfett in Broilerschlachtkörpern. Im Alter von 42 Tagen konnten 308 Ross 30 Küken (Geschlecht 1:1) geschlachtet und zerlegt werden. Aus dem rechten Flügel und Bein wurden 17 Muskeln sowie die rechten und linken Brustmuskeln ausgelöst und deren Gewichte in Beziehung zu Schlachtkörpermerkmalen gesetzt. Die höchsten Korrelationskoeffizienten fanden sich für die Beziehung der Brustmuskeln zum Fleischgewicht (rechter und linker Muskel $r=0,81$ bzw. 0,82 ) gefolgt vom M. gastrocnemius mediale $r=0,81$ sowie $M$. peroneus superficialis $r=0,73$. Für die Beziehungen zwischen einzelnen Muskeln zu Haut und Fett fanden sich mit $r=0,04$ bis 0,29 weit niedrigere und nicht signifikante Koeffizienten. Lediglich die Beziehung zwischen M. pectoralis zu Haut und Fett erwies sich mit $r=0,42$ als signifikant.

Schlüsselwörter: Broiler, Bemuskelung, Verfettung, Fleischigkeit, Korrelation 


\section{Introduction}

Studies aimed at determining indicators that could be used for an in vivo and post mortem analysis of meatiness and fatness in poultry carcasses have been conducted for years (ANDRASSY-BAKA et al. 2003, BERRI et al. 2005, KLECZEK et al. 2009, RYMKIEWICZ and BOCHNO 1999, SHAHIN and ABD EL AZEEM 2005, 2006, WAWRO et al. 1983). The indicators determined after slaughter cannot serve as a selection tool, but may be applied to evaluate the results of animal improvement programs. Therefore, indicators that would be easy to measure and highly correlated with carcass tissue composition are continuously searched for.

The most precise method for the estimation of carcass tissue composition is detailed dissection. However, this method is labour-consuming and substantially decreases the processing suitability of raw material. The dissection of a single muscle requires lower labour expenditures and does not considerably deteriorate overall carcass quality.

WAWRO et al. (1984a) demonstrated that meat weight in goose carcasses was correlated to the highest degree with the weight of $\mathrm{m}$. anconeus longus, $m$. gastrocnemius mediale and $m$. gastrocnemius laterale $(r>0.8)$, while fat weight - with the weight of leg muscles: $m$. fiburalis peroneus superficialis, $m$. gastrocnemius laterale and $m$. semitendinosus ( $r>0.6)$. In duck carcasses, the weight both lean meat and fat showed the highest correlation ( $r>0.7$ ) with the weight of breast muscles and m. gastrocnemius mediale (WAWRO et al. 1984b). Thus, it seems that the weight of individual muscles may be a good indicator of carcass meatiness and fatness in waterfowls.

The objective of this study was to test whether the weight of selected arm and leg muscles and breast muscles may be used as an indicator of the content of lean meat and skin, including subcutaneous and abdominal fat, in the carcasses of broiler chickens.

\section{Material and methods}

The experimental materials comprised 40 Ross 308 chicks aged 42 days (sex ratio 1:1). After $12 \mathrm{~h}$ fasting, the birds were weighed and slaughtered. Following removal of the head and feet, carcasses were chilled at $4^{\circ} \mathrm{C}$ and, on the next day, were weighed and divided into neck, wings, legs, breast and back. The breast and legs were weighed and dissected into lean meat, bones and skin including subcutaneous and intermuscular fat.

A total of 17 muscles were dissected from the right wing and the right leg: $m$. deltoideus maior, $m$. biceps brachii, $m$. triceps brachii, $m$. coracobrachialis posterior, $m$. extensor matacarpi ulnaris, m. indicius longus, $m$. extensor digitorum communis, m. flexor carpi ulnaris, $m$. sartorius, $m$. tensor fasciae latae, $m$. biceps femoris, $m$. semitendinosus, $m$. semimembranosus, m. peroneus superficialis, m. tibialis anterior, m. gastrocnemius laterale, m. gastrocnemius mediale. The right and left breast muscles were also dissected. In the present study, the term »fat with skin « refers to abdominal fat and skin together with a subcutaneous fat layer which are difficult to separate in poultry.

The statistical analysis of the collected data included the determination of the characteristics of the analyzed traits $(\bar{x}, S D)$. Coefficients of simple correlation $(r)$ between the weight of individual muscles $(x)$ and selected slaughter quality parameters $\left(y_{i}\right)$ were calculated (STATISTICA 2008). 


\section{Results and discussion}

The average body weight and carcass weight of chickens were $2703 \mathrm{~g}$ and $1998 \mathrm{~g}$ respectively. The lean meat content of a carcass was $1343 \mathrm{~g}$, and the content of skin, subcutaneous and abdominal fat $-304 \mathrm{~g}$ (Table 1).

Table 1

Body weight, carcass weight, total meat weight and the weight of skin and fat in broiler carcasses

Lebend-, Schlachtkörpergewicht, Gesamtgewicht von Fleisch und Haut samt Fett in den Hähnchenschlachtkörpern

\begin{tabular}{lrr}
\hline Specification & $\bar{x}$ & Statistics \\
\hline Body weight, g & 2703.0 & 287.5 \\
Carcass weight, g & 1998.0 & 226.2 \\
Meat weight, g & 1343.4 & 154.4 \\
Weight of fat with skin, g & 303.9 & 52.1 \\
\hline
\end{tabular}

Table 2

The weight of breast, arm and leg muscles, and the coefficients of simple correlation between the weight of these muscles and the weight of lean meat, skin and fat in broiler carcasses

Gewicht von Brust, Bein und einzelnen Flügelmuskeln sowie Kennziffer der einfachen Korrelation zwischen dem Gewicht dieser Muskeln und dem Gewicht von Fleisch und Haut samt Fett in den Hähnchenschlachtkörpern

\begin{tabular}{|c|c|c|c|c|}
\hline \multirow[t]{2}{*}{ Specification } & \multicolumn{2}{|c|}{ Statistics } & \multicolumn{2}{|c|}{$\begin{array}{c}r_{x y} \text { between weight of analyzed } \\
\text { muscles and weight of }\end{array}$} \\
\hline & $\bar{x}$ & SD & Meat & Fat with skin \\
\hline \multicolumn{5}{|l|}{ Weight of breast and arm muscles, $\mathrm{g}$} \\
\hline M. pectoralis & 279.7 & 38.7 & $0.81^{* *}$ & $0.42^{* *}$ \\
\hline M. pectoralis & 275.7 & 37.8 & $0.82^{* *}$ & $0.42^{* *}$ \\
\hline M. deltoideus maior & 4.5 & 0.6 & $0.50^{* *}$ & 0.11 \\
\hline M. biceps brachii & 7.0 & 1.0 & $0.60^{* *}$ & 0.18 \\
\hline M. triceps brachii & 10.5 & 1.4 & $0.57^{* *}$ & 0.17 \\
\hline M. coracobrachialis posterior & 2.4 & 0.5 & $0.38^{*}$ & 0.28 \\
\hline M. extensor matacarpi ulnaris & 3.3 & 0.6 & $0.55^{* *}$ & 0.22 \\
\hline M. indicius longus & 1.4 & 0.4 & $0.47^{* *}$ & 0.04 \\
\hline M. extensor digitorum communis & 1.2 & 0.6 & $0.62^{* *}$ & 0.08 \\
\hline M. flexor carpi ulnaris & 2.7 & 0.5 & $0.62^{* *}$ & 0.29 \\
\hline \multicolumn{5}{|l|}{ Weight of leg muscles, $\mathrm{g}$} \\
\hline M. sartorius & 9.2 & 1.7 & $0.69^{* *}$ & 0.24 \\
\hline M. tensor fasciae latae & 6.3 & 1.2 & $0.68^{* *}$ & 0.15 \\
\hline M. biceps femoris & 25.2 & 5.2 & $0.68^{* *}$ & 0.23 \\
\hline M. semitendinosus & 13.0 & 2.7 & $0.66^{* *}$ & 0.23 \\
\hline M. semimembranosus & 16.5 & 4.0 & 0.15 & 0.13 \\
\hline M. peroneus superficialis & 10.2 & 1.6 & $0.73^{* *}$ & 0.07 \\
\hline M. tibialis anterior & 11.4 & 1.9 & $0.69 * *$ & 0.18 \\
\hline M. gastrocnemius laterale & 19.7 & 2.9 & $0.68^{* *}$ & 0.16 \\
\hline M. gastrocnemius mediale & 12.3 & 2.1 & $0.81^{* *}$ & 0.23 \\
\hline
\end{tabular}

Significance of correlation coefficients $\left(r_{x y}\right):{ }^{*}$ at a level of $a=0.05,{ }^{* *}$ at a level of $a=0.01$.

The weight of the analyzed muscles varied within a relatively wide range (Table 2). Wing muscles, m. extensor digitorum communis and $m$. indicius longus ( $1.2 \mathrm{~g}$ and $1.4 \mathrm{~g}$ respectively) as well as $m$. coracobrachialis posterior $(2.4 \mathrm{~g})$ and $m$. flexor carpi ulnaris $(2.7 \mathrm{~g}$ ) were characterized 
by the lowest weight. Much higher weight was reported for leg muscles (Table 2): $m$. biceps femoris (25.2 g), m. gastrocnemius laterale (19.7 g) and $m$. semimembranosus (16.5 g), while breast muscles were found to be heaviest (average weight of both muscles $-555.4 \mathrm{~g}$ ).

The highest correlation was noted between the lean meat content of a carcass and the weight of the right and left breast muscles ( $r=0.81$ and 0.82 respectively), $m$. gastrocnemius mediale $(r=0.81)$ and $m$. peroneus superficialis $(r=0.73)$. High values of correlation coefficients were also found for the following muscles: $m$. sartorius, $m$. tibialis anterior, $m$. tensor fasciae latae, $m$. biceps femoris, $m$. gastrocnemius laterale, $m$. semitendinosus, $m$. extensor digitorum communis, $m$. flexor carpi ulnaris and $m$. biceps brachii ( $r$ from 0.60 to 0.69). Significant dependencies were also observed between the lean content of broiler carcasses and the remaining muscles (except for $m$. semimembranosus), but in this case the coefficients of simple correlations were much lower ( $r$ from 0.38 to 0.57 ). Only the weight of $m$. semimembranosus was not correlated with meat weight $(r=0.15)$. WAWRO et al. (1984a) demonstrated that meat weight in goose carcasses was correlated to the highest degree with the weight of $m$. anconeus longus $(r=0.894), m$. gastrocnemius mediale $(r=0.827)$ and $m$. gastrocnemius laterale $(r=0.801)$, while fat weight - with the weight of leg muscles: $m$. fiburalis peroneus superficialis, $m$. gastrocnemius laterale and $m$. semitendinosus $(r>0.6)$. In duck carcasses, the weight of lean meat also showed the highest correlation ( $r>0.7)$ with the weight of breast muscles $(r=0.845)$ and $m$. gastrocnemius mediale ( $\mathrm{r}=0.759$, WAWRO et al. 1984b).

According to previous studies of indirect methods for meatiness estimation in poultry, among the traits determined after slaughter, carcass weight and the weight of breast and leg muscles showed the highest correlation with the meat content of a carcass (BOCHNO et al. 1989, BOCHNO et al. 1999, JANISZEWSKA et al. 1990, RYMKIEWICZ and BOCHNO 1999, RYMKIEWICZ et al. 1999, WAWRO et al. 1983). BOCHNO et al. (1999), RYMKIEWICZ and BOCHNO (1999) and RYMKIEWICZ et al. (1999) observed high values of correlation coefficients ( $r$ approximately 0.8 ) between body weight and the weight of breast and leg muscles in the carcasses of geese, chickens and ducks.

The prediction of the weight of skin and fat in the carcasses of broilers based on the weight of single muscles may be unreliable due to low and non-significant values of correlation coefficients ( $r$ from 0.04 to 0.29 , Table 2 ). The weight of this tissue component was significantly correlated $(r=0.42)$ with breast muscle weight only. Similar results were reported by WAWRO et al. (1984b) with respect to Pekin ducks. The correlation between the weight of the analyzed muscles and carcass fatness was relatively low. Different results were obtained in studies of geese (WAWRO et al. 1984a), where the highest correlation was noted between fat weight in the carcass and the weight of leg muscles $m$. fiburalis peroneus superficialis $(r=0.711), m$. gastrocnemius laterale $(r=0.630)$ and m. semitendinosus $(r=0.611)$.

According to other authors (WAWRO et al. 1983) carcass fatness may be estimated based on the values of other traits, i.e. carcass weight and the weight of abdominal and periintestinal fat.

In conclusions the weight of both breast muscles, as well as of $m$. gastrocnemius mediale and $m$. peroneus superficialis $(r>0.70)$, was found to be useful for a post mortem estimation of carcass meatiness in broiler chickens. The prediction of the weight of skin and fat in the 
carcasses of broilers based on the weight of single muscles may be unreliable due to low and non-significant values of correlation coefficients ( $r$ from 0.04 to 0.29 ).

\section{References}

Andrassy-Baka G, Romvari R, Militis G, Sütö Z, Szabo A, Locsmandi L, Horn P (2003) Non-invasive body composition measurement of broiler chickens between 4-18 weeks of age by computer tomography. Arch Tierz 46, 585-95

Berri C, Debüt M, Lebihan-Duval E, Sante-Lhoutellier V, Hattab N, Jehl N, Duclos M (2005) Technilogical quality of broiler breast meat in relation to muscle hypertrophy. Arch Tierz 48 Special Issue, 131

Bochno R, Rymkiewicz J, Janiszewska M (1999) Multiple regression equations for estimation of the content of breast muscles in white italian geese. In: 12th Europ Symp on Waterfowl, Adana, Turkey, 83-9

Bochno R, Rajkiewicz H, Lewczuk A, Janiszewska M (1989) Using multiple regression equations for estimation of meatiness of meat-type hens. In: 8th International Symp on Current Problems of Avian Genetics, Smolenice, Czechoslovakia, 70-3

Janiszewska M, Lewczuk A, Bochno R, Rajkiewicz H (1990) Accuracy of carcass meatiness estimation with the use of multiple regression equations in hens of various strains. Prz Nauk Lit Zoot 35, 205-9 [in Polish]

Kleczek K, Wawro K, Wilkiewicz-Wawro E, Makowski W, Konstantynowicz D (2009) Relationships between breast muscle thickness measured by ultrasonography and meatiness and fatness in broiler chicken. Arch Tierz 52, 538-45

Rymkiewicz J, Bochno R (1999) Estimation of breast muscle weight in chickens on the basis of live measurements. Arch Geflügelk 63, 229-33

Rymkiewicz J, Schymczyk J, Bochno R (1999) Use of statistical methods to improve the quality of duck carcasses. In: Intern Sci Conf »Problems of Animal and Poultry Meat Production Increasing and Quality Improvement", Kaunas, Lithuania, 153-7

Shahin KA, Abd El Azeem F (2005) Effects on breed, sex and diet and their interaction on carcass composition and tissue weight distribution of broiler chickens. Arch Tierz 48, 612-26

Shahin KA, Abd El Azeem F (2006) Effect of breed, sex and diet and their interactions on fat deposition and partitioning among depots of broiler chicken. Arch Tierz 49, 181-93

Statistica (2008), Statistica version 8, StatSoft Inc, Tulsa, OK, USA

Wawro K, Bochno R, Janiszewska J, Lewczuk A, Mazanowski A (1983) Suitability of selected traits determined in vivo and post mortem for estimation of the meat, fat and bone content of a carcass in ducks of various breeding lines. Prz Nauk Lit Zoot 28, 244-51 [in Polish]

Wawro K, Bochno R, Wawro E (1984a) Suitability of the weight of selected muscles for estimation of the content of tissue components in goose carcasses. Zesz Nauk ART Olszt Zoot 26, 103-11 [in Polish]

Wawro K, Bochno R, Wawro E (1984b) Suitability of the weight of selected muscles for estimation of the content of tissue components in the carcasses of ducks slaughtered at a different age. Zesz Nauk ART Olszt Zoot 27, 173-81 [in Polish]

Received 1 April 2009, accepted 11 December 2009.

Corresponding author:

KATARZYNA KLECZEK

email: katarzyna.kleczek@uwm.edu.pl

Department of Commodity Science and Animal Improvement, University of Warmia and Mazury,

Oczapowskiego 5, 10-719 Olsztyn, Poland 